\title{
The Romanian language in Habsburg Bukovina from the institutionalized bilingualism perspective
}

\author{
Ana-Maria Prisacaru ${ }^{\mathbb{R}^{\mathrm{R}} \star}$ \\ “A. Philippide” Institute of Romanian Philology, Str. Th. Codrescu 2, 700481 Iași, Romania
}

\section{Article info}

History:

Received September 28, 2020

Accepted October 16, 2020

Published December 27, 2020

Cuvinte-cheie:

Bukovina

the Habsburg Empire

bilingualism

reformation

Germanization

\begin{abstract}
From the perspective of the power relationships manifested in a territory under foreign occupation, institutionalized bilingualism involves the differentiation between the languages coming into contact and their hierarchization according to the communicative functions they are to fulfill within the new state organization governed by a sovereign authority. A linguistic phenomenon that proves to be unbalanced as far as the interfering languages are concerned, this type of bilingualism imposed the German language in Habsburg Bukovina as the only language used in the "administrative structures of the country", officially declared as such in Northern Moldavia in 1784. The fact that the communication functions of the Romanian language were almost exclusively limited to the colloquial register is the result of an intense policy of linguistic "leveling" (Ausgleichspolitik), implemented by the Court of Vienna in all its imperial provinces in order to reduce national specificity by means of imposing the use of the German language. The cohesion and uniformity of all Habsburg territories was only possible through the reformation, according to the Josephine principles, of the institutions responsible with the preservation of the national identity of the subjugated nations. In Bukovina, the juridical-administrative, church and school sectors were targeted, being affected by the Germanization process especially after the North of Moldavia was incorporated into the Kingdom of Galicia and Lodomeria.
\end{abstract}

\section{Introduction}

For Northern Moldavia, the year 1774 marked its separation from the mother-country and annexation to the Habsburg Empire. The annexation act was signed by Turkey, Austria and Russia, the three great European powers, in a political-diplomatic context following the end of the Russian-Turkish War (17681774) resulting in the defeat of the Sublime Porte. In exchange for military aid, Austria was given by the Sublime Porte the "key of Moldavia" (der Schlüssel der Moldau), a territory that was to be named Bukovina, regarded by the Court of Vienna as a junction point between Transylvania, Maramureș and Galicia, perfect for "facilitating communication and commerce" and "ensuring the exchange of supplies for the troops, from one province to the other, in case of war" (Kogălniceanu, 1911, p. 11).

At the time of the annexation of Bukovina, the state policy of the Habsburg Monarchy was dominated by the Josephine doctrine principles that aimed, on the one hand, at the "centralization and standardization" (Ceauşu, 1998, p. 26) of all Habsburg territories in order to consolidate the cohesion of the Empire and on the other hand, at placing all the fields of activity in the annexed provinces under state control. At the beginning, during the military administration period (1774-1786), the Court of Vienna kept its promises with regard to the preservation of the traditional status-quo in Bukovina. Although proposals to reorganize the province were made ever since the end of $1774^{1}$, Joseph II was reluctant to such suggestions,

\footnotetext{
${ }^{\star}$ Email address: carpanamaria@yahoo.co.uk.

${ }^{1}$ Reference is made here to the first measures proposed to the Court of Vienna by the first governor of Bukovina, general major Gabriel Spleny von Mihaldy: "removing Moldavians from all administrative or juridical positions and replacing them
} 
being aware that "people were extremely fond of their customs and traditions" (Nistor, 1991, p. 45). Given the desire to encourage demographic growth in the newly annexed territory, the emigration to Moldavia of Bukovinians who were unsatisfied with the sudden changes was practically inconceivable. However, it was decided to reduce the number of monasteries and to transfer their lands and funds under the state administration.

Nevertheless, the fate of Bukovina was to change beginning with the year 1786 when, in the spirit of Josephine 'centralism' that aimed at merging neighboring provinces for mainly economic reasons, the North of Moldavia became part of the Kingdom of Galicia and Lodomeria. This was a period of profound political, administrative, church and school re-structuring, reforms aimed at Germanization that implicitly altered the status of the Romanian language as the official language in Bukovina. Under civil administration, the Moldavian territory will finally be subordinated to the same governing regime implemented in all imperial provinces, which was represented, at the linguistic level, by the well-known 'leveling' policy (Ausgleichspolitik), by means of which the House of Habsburg "intended to attenuate ethnic disputes and contradictions, pleading for the abandonment of national specificity" by "giving up national languages and using a single language, namely German” (Moldoveanu, 1998, p. 224).

\section{Institutionalized bilingualism in Habsburg Bukovina}

The enforcement of the German language as the official language in Bukovina starting with the year 1784 created the context for a phenomenon known as institutionalized bilingualism, specific to territories under foreign occupation, reflecting the power relationship governing those territories and resulting in "a differentiated status of the languages coming into contact, with differences deriving from the role assigned by the state administration to each of these languages” (Guțu-Romalo, 2004, p. 34). Starting from the premise that he who does not speak the language of the Empire "will become a badly educated man of absolutely no use to the state" (Aurel Morariu, Bucovina (1774-1914), p. 39, apud Moldoveanu, 1998, p. 20), the German language eventually governed the hierarchy generated by this type of unequal bilingualism, being used in all institutions with an essential role in preserving the national identity of the people of Bukovina: justice, administration, school and church. Functionally limited almost exclusively to the colloquial register, the Romanian language was accepted in the context of institutionalized bilingualism only with a "secondary' idiom status, restricted in carrying out its communicative functions by the limitation of its social attributions within the state structure in which it operates" (Chivu, 2004, p. 36).

Institutionalized bilingualism did not affect the rural environment, where Romanian was still the only language spoken in the family. However, in the urban environment, both the German language, largely used in administration, trade and crafts, and the Polish language, spoken by the immigrants from Galicia, tended to undermine the status of the Romanian language. Attracted by the equivalence of boyar ranks with imperial nobility ranks, many Romanian boyars adhered to the Nobility Forum of Bukovina (Forum Nobilium, created in 1804), although they would not enjoy the same privileges as their Galician counterparts. However, in many circles of noblemen, German and Polish were spoken not only when it came to official matters, but also within the family. Polish was regarded as "fashionable" and therefore was spoken in order to impress. Acculturation gradually infiltrated "the cultivated society" generating "a broken Romanian, with constructions and phrases closely following the German models" (Moldoveanu, 1998, p. 126) being also favored by the secondary and higher bilingual education; consequently, many of the students mastered neither Romanian nor German: "when they use Romanian, their writing and speech is full of German phrases, and when they turn to German, they use Romanian words and phrases" (Greciuc, 1912, p. 32). This phenomenon is depicted by Ion Nistor (1916, p. 11), who points out that the

with officers; the subordination of the whole state apparatus to the military governor, with headquarters in Chernvitsi; the establishment of two courts of law, led by officers, each assisted by a German 'chancellor' and two Moldavians; assigning all economic, social-political and religious issues to the military commander of the area, assisted by a committee of officers" (Iacobescu, 1993, p. 117). 
pure Romanian language was only to be found "in the peasants' homes [...] and at the courts of the few boyars remaining in Bukovina”. However, the situation is not as serious as in Tsarist Bessarabia, where the aggressive Russianization policies was aimed at discrediting the Romanian language and basically cancelling its functionality in the social-cultural context"2:

'Moldavian' Romanians, forced by an intense propaganda to perceive the 'peasant-like', 'noncivilized' character of their mother tongue, were constrained to accept the Russian language, or at least massive influences of the Russian language even for their common daily conversation. Denationalization turned thus from state policy into an individual cultural option (Chivu, 2004, p. 81).

\section{Romanian language in Habsburg Bukovina from the perspective of the juridical-administrative reformation}

At the moment of annexation, the North of Moldavia was marked by a profound Romanian character: the majority of the population was Romanian and the main part of the population spoke Romanian, a fact confirmed by Ion Budai-Deleanu (1813, p. 385), who notes that the people from Bukovina used to speak "the old popular Romanian language, mixed with various Slavonic, Greek and Albanian words, but these words borrowed from other languages represented merely a third of the spoken language". In the first stage of the Habsburg governing, when the preservation of the Bukovinians' identity was promised, the Romanian language had, de facto, a similar status with the German language. This was proven by the fact that all public and official documents at the time were either printed in Romanian, or bilingual. Ion Nistor performed an inventory of 96 bilingual leaflets addressed to Bukovinians. When it came to legal matters, all legal orders that responded the requests formulated by the Bukovinians were written in Romanian. Moreover, all imperial officials, including Bukovina's second governor, general Enzenberg, were appointed on the condition that they also spoke Romanian. However, these rules regarding the Romanian language were subsequently broken, as it was difficult to accept that "in one province, laws and public affairs were treated in the national language" (Torouțiu, 1916, p. 44).

The first sector to be affected by the Germanization process, with linguistic repercussions, was the juridical-administrative sector. Reformation began with small steps and was seemingly in favor of maintaining the status of the Romanian language. It should be noted that initially, Joseph II demanded that the key positions in the administrative administration, namely the ones of district leader and district ispravnic (clerk or boyar in charge of law enforcement in a certain country) be occupied by clerks brought from Banat and Transylvania, as they spoke both German and Romanian. Even the Austrian Constitution was translated into Romanian in 1786, to render it accessible to the Moldavians. Subsequently, "sensitive" to the pretexts invoked by Spleny, namely that the Moldavians holding juridical-administrative positions were only familiar with the "local customs and Romanian laws" and were "under the influence of the church and the priests" (Iacobescu, 1993, p. 116), the Court of Vienna decide to marginalize them or replace them with foreign clerks, since it actually needed subjects who were loyal to the Empire and adhered to the Josephine reformist ideas. The juridical and administrative reformation was even more obvious after the annexation of Bukovina to Galicia, which opened the way for "Slavonic immigration and the import of Galician clerks" (Ștefanelli, 1911, p. 29). Since none of these foreign officials spoke Romanian, German naturally gained ground as the only language used in the field. At the beginning of the $19^{\text {th }}$ century, when the Vienna government adopted a new reform for the "unification of the Greek-Orthodox beliefs of the Eastern peoples with the glorious dominant Roman-Catholic Church" (see infra), there is a new obstacle for any Moldavian aspiring for an administrative position: besides a good knowledge of the German

\footnotetext{
${ }^{2}$ In this respect, the linguistic policy culminates with the creation of the glotonym 'Moldavian language' used to designate an Eastern European Romance language that was different from Romanian.
} 
Ana-Maria Prisacaru

language and a compulsory education in German schools, they had to convert to the Catholic church. In these circumstances, according to historical sources, in 1910, out of a total of 627 clerks working in the juridical-administrative system, only 87 were Romanians (cf. Iacobescu, 1993, p. 267).

\section{Romanian language in Habsburg Bukovina from the perspective of the co-dependent ecclesiastical and school reforms}

More severe implications upon the status of the Romanian language in Bukovina resulted from the restructuring operated by the Habsburg authorities in the ecclesiastic and education fields, as the cohesion of the imperial provinces was only possible by transferring church properties into state property and by means of an elaborate educational reform aimed, on the one hand, at "restraining the local national specificity" and on the other hand, at providing Bukovinians with "a minimum of culture and moral-civic education that would make them more valuable and useful for the state" (Ceaușu, 1998, p. 119, 232). The starting point of the co-dependent reforms in the two sectors was the closure of the churches and the secularization of church properties. In 1783, out of political and economic-financial reasons, Joseph II ordered that of the 17 monasteries, 15 hermitages and 4 retreats in Bucovina, only the monasteries of Putna, Sucevita and Dragomirna remained open, each with a maximum of 25 monks. As the Bucovina clergy was subordinated to the Metropolitan Church of Iași and, therefore, the entire monastic wealth obtained from the 267 properties went to Moldova, the Imperial Court decided in the same year to subordinate the Bukovina church in dogmaticis et mere spiritualibus to the Serbian Metropolitan Church of Karlovci, after in 1781 it had been decided, as a first measure of separation from the clergy of Moldavia, to establish an autonomous diocese in Bukovina.

The ecclesiastical reform continued with the establishment of the Greek-Oriental Religious Fund of Bukovina, known as the Church Fund, with the stated purpose of sustaining Orthodox priests and church staff, educating priests and establishing public schools in each village with a parish. However, in 1786, this fund was removed from the supervision of the Orthodox Consistory, which would henceforth had the right to rule only on matters "related to dogma and the purely spiritual" (Nistor, 1921, p. 20), and was transferred under the administration of Galicia, finally serving Catholic schools that used to teach in German and Polish.

The Romanian language, about which the Church Regulation (or the Regulation Plan for the monasteries and schools in Bucovina) of 1786 stipulated that it must be "the official language of the diocese, as well as of the religious office within it" (Moldoveanu, 1998, p. 19), lost this function after the incorporation of Bukovina into Galicia. Concerned about the strong influence of the Orthodox Church on the Bukovinians, an influence felt to be a threat to Germanization policy, the Court of Vienna, guided by the principle of divide et impera, favored the spread of Catholicism by building Roman Catholic churches for the German colonists and Greek Catholic churches for the Ruthenians and Hutsuls who had immigrated from Galicia. This strategy culminated in the time of Daniil Vlahovici, appointed bishop of Bukovina after Dosoftei's death, by elaborating the Plan for finally achieving the union of the Greek, Orthodox faith of the Eastern peoples with the glorious dominant Roman Catholic church [...], a plan aimed at attracting the Bukovinian Orthodox people to the dominant denomination of the Habsburg Empire. Although the Romanians never gave up their religion, all these measures were intended to increase the intrusion of the Court of Vienna in the religious life in Bukovina, with the main purpose of placing the church under state control and, implicitly, reducing the influence of the Romanian clergy to merely religious issues so that they lost their power of decision over the management of the church funds and the organization of the Romanian education system.

Foreign historical sources (Ferdinand Zieglauer, R.F. Kaindl, Johann Polek, Erick Prokopowitsch and others) note that at the time of annexation, Bukovina had a precarious school network. Extremely eloquent in this respect are Polek's mentions (1899, p. 126):

The spiritual culture of the locals was at the lowest level. There were, indeed, a few monastery 
schools in Putna, Rădăuţi and Suceava, yet they were only aimed at teaching future priests the minimum knowledge they needed for their service. The masses lived with no education at all.

Without disregarding the significant impact the imperial reforms had upon the Romanian education, we should still mention that in Moldavia there were princely schools functioning since 1766 in Putna, Siret, Suceava, Cernăuți, Rădăuți and Cîmpulung Moldovenesc. Moreover, primary schools, although rudimentary, existed in many towns and villages, as well as near several monasteries. The first step in the modernization and Germanization of the educational system was bilingual education: in 1774, Spleny proposed the establishment of a Romanian-German school in Suceava that could train Bukovinians aspiring to administrative functions. There followed, in 1780, the decision of the Aulic War Council to establish "not only Wallachian, but also German schools" at least in Chernvitsi, Suceava and Siret (Iacobescu, 1993, p. 279), that could be attended by both Romanian children and the German colonists' children. Consequently, two normal German-Romanian schools were opened in Chernvitsi and Suceava. These were followed by the schools in Zastavna, Vășcăuți, Cîmpulung pe Ceremuș, but also by trivial schools opened near village parishes, all theoretically using Romanian as the language of teaching ${ }^{3}$, under the coordination of the Orthodox Consistory of Chernvitsi and receiving funding from the Church Fund. Thus, between 1786 and 1792, 32 schools are recorded in Bukovina ${ }^{4}$, a context that favored all Bukovinians who were willing to learn; however, starting with 1793 , when compulsory education was no longer mandatory, mainly due to financial reasons, many of those schools closed their gates. According to Iacobescu (1993, p. 282), in 1804 there were just 14 active schools "that propagated the German language and culture, the Catholic faith and the imperial conservatory views". Starting with 1816, when the education system was placed under the control of the Catholic Consistory in Lemberg, the situation became even worse, as Polish was also introduced in schools. In addition, Romanian teachers' chances to teach in schools in Bucovina decreased dramatically, given that, besides having a good knowledge of the German language, they were also required to convert to Catholicism, the dominant religion in Galicia. Although Joseph II initially demanded that in northern Moldavia the schools have "a pure national and confessional foundation" (Iacobescu, 1993, p. 286) and that teaching should be done by teachers who spoke Romanian, the Romanian teachers were gradually replaced by foreigners, mostly Catholic priests from Galicia, unfamiliar with the "language of the country". Gradually, the Romanian language in the school system during the civil administration was replaced by German, the official language of the Empire, and also by Polish, the official language of Galicia. This is proven by a decision issued in 1824 by the Galician government that stipulated that "Romanian should be used only when necessary to explain the lesson" (Bogdan-Duică, 1895 , p. 55). As expected, the Bukovinians, who strongly disagreed with this policy of denationalization, refused to send their children to schools where German or Polish teachers no longer addressed the children in their mother tongue. In addition, from 1805, primary education started to acquire a confessional character. In other words, a school became Orthodox or Catholic, depending on the confession of the local priest. This imperial order was totally unfavorable to the Orthodox community if we consider the percentage of Catholic foreigners who had settled in numerous localities in Bukovina. Even worse was the fact that, in an attempt to apply that Plan to merge Orthodoxy with the "glorious dominant Roman Catholic Church" (see supra), Romanian primary schools were declared Catholic confessional schools in

\footnotetext{
${ }^{3}$ A decision from the Aulic War Council from 1783 stipulated that primary school teachers, many of them brought from Transylvania, "should speak the language of the country, namely Romanian, besides Latin and German" (Nistor, 1991, p. 275). This condition was often disregarded, if we take into account the fact that there were teachers such as Franz Thaillinger, an important personality of the normal school in Suceava, who did not speak any Romanian at all. At the clerical school of the Saint Ilie Monastery in Suceava, aimed at educating Orthodox priests and financed by the church of Bukovina, the disciplines were taught in German and the Serbian Daniil Vlahovici was appointed headmaster.

${ }^{4}$ Reference is made to the normal schools where the future administrative clerks and teachers for the trivial schools were trained, the main schools that provided access to richer children, preparing them for secondary administrative functions, as well as to the trivial schools, aimed at providing basic writing, reading and mathematics skills for the children in rural areas, since one of the constant preoccupations of the Josephine policy was to help lower social classes progress through culture.
} 
Ana-Maria Prisacaru

1815, subordinate to the Roman Catholic Consistory in Lemberg, yet supported from the very church fund initially destined for the development of the purely Romanian school system. The latter measure generated "the almost total liquidation of the Romanian school network, by removing Romanian teachers and professors, by removing the national language and culture from the schools" (Iacobescu, 1993, p. 298).

The Revolution of 1848 recorded a notable victory for the Romanian education as, with the establishment of the normal school in Chernvitsi, destined for future teachers in Bukovina, Romanian language and literature were reintroduced as disciplines of study. This first victory was followed by the decision of the Imperial Court to reintroduce Romanian, as a teaching language, at the Theological Institute of Chernvitsi and establishing a department of Romanian language at the German High-school in Chernvitsi. The education system was to return under the supervision of the Orthodox Consistory in 1850, when the schools attended by Romanian children regained their Orthodox character.

\section{Conclusions}

Despite the fact that throughout the Habsburg occupation the Romanian language had the status of an official language in Bukovina, the reforms operated by the Vienna Court in order to reduce the national specificity - reforms applied in all the imperial provinces - resulted in its removal from all the institutions responsible for preserving the identity consciousness of the people of Bucovina. The Josephine policy of linguistic "leveling" (see supra) was carried out, on the one hand, by restructuring the legal-administrative apparatus, seized, especially after the incorporation of Bukovina into Galicia, by foreign officials who did not speak the language of the country, so that the use of German become mandatory in this sector. Following the nationalization of the church, the Imperial Court had absolute decision-making power over the administration of ecclesiastical wealth and the organization of the school system.

Although the cultural perspectives opened by the imperial reforms for the Romanians in Bukovina are not to be contested, it is still regrettable that Romanian, despite being an official language, was for a long while only used to teach religion in some schools. As far as power relations were concerned, the access of the people in Bucovina not only to the legal-administrative structures, but also to quality schooling was conditioned by the acquisition and use of the language of the Empire. At least until 1869, when, by an imperial decision, "the kingdom acknowledged the fact that all the languages of a country are equally entitled to be spoken in schools, in the administration system and in the public life" (Moldoveanu, 1998, p. 112), secondary and higher education functioned under the monopoly of the German language, while primary education was marked by the infiltration of the Polish language. Starting with the period when the territory of Bukovina acquired provincial autonomy, as a duchy, the Romanian language started to gain ground in exercising its communicative functions in all "the administrative structures of the country" due to the tireless efforts of the Romanian intellectuals of the time. But its reconfirmation as the only official language used in northern Moldavia would only occur in 1918, with the union of Bukovina with Romania.

\section{Bibliography}

Bogdan-Duică, G. (1895). Bucovina - notițe politice asupra situației, Institutul Tipografic T. Liviu Albini, Sibiu.

Budai-Deleanu, I. (1813). Scurte observații asupra Bucovinei, in Bucovina în primele descrieri geografice, istorice, economice și demografice, ediție îngrijită de Radu Grigorovici, Editura Academiei Române, București, p. 373-429.

Ceaușu, M.-Șt. (1998). Bucovina habsburgică de la anexare la Congresul de la Viena. Iosefism și postiosefism (1774-1815), Fundația Academică „A.D. Xenopol”, Iași.

Chivu, Gh. (2004). Limba oficială din Republica Moldova și unitatea culturii românești, in Grecu, A. (ed.), Unitatea limbii române, cu privire specială la Basarabia și Bucovina, Editura Academiei Române, București, p. 79-87.

Greciuc, V. (1912). Utracvismul sau două limbi de predare la liceele (gimnaziile) românești din Bucovina, Tip. Soc. „Școala Română”, Cernăuți.

Guțu-Romalo, V. (2004). Evoluția limbii române în Republica Moldova, in Grecu, A. (ed.), Unitatea limbii române, cu privire specială la Basarabia și Bucovina, Editura Academiei Române, București, p. 33-48.

Iacobescu, M. (1993). Din istoria Bucovinei, Vol. I (1724-1862). De la administrația militară la autonomia provincială, Editura Academiei Române, București. 
Kogălniceanu, M. (1911). Răpirea Bucovinei, ediția a 2-a, Editura „Neamul Românesc”, Vălenii de Munte.

Moldoveanu, Gh. (1998). Limba română în Bucovina. Statutul socio-cultural și politic, Editura A92, Iași.

Nistor, I. (1916). Un capitol din vieața culturală a românilor din Bucovina, 1774-1857. Discurs rostit la 21 maiu (3 iunie) 1916 în sedință solemnă de I. Nistor, cu răspuns de N. Iorga, in Academia Română. Discursuri de recepțiune, vol. 44, Librăriile Socec et Co., C. Sfetea, Pavel Suru, București, p. 3-64.

Nistor, I. (1921). Istoria fondului bisericesc din Bucovina, Institutul de Arte Grafice și Editura „Glasul Bucovinei”, Cernăuți. Nistor, I. (1991). Istoria Bucovinei, ediție nouă, Editura Humanitas, București.

Polek, J. (1899). Die Besitzergreifung, in Die Österreichisch-ungarische Monarchie in Wort und Bild: Bukowina (Band 20.), Viena, p. 116-127.

Ștefanelli, T.V. (1911). Istoricul luptei pentru drept în ținutul Cîmpulungului-Moldovenesc, Librăria Socec \& Comp., București. Torouțiu, I.E. (1916). Poporația și clasele sociale din Bucovina, Editura Lupta, București. 